\title{
The impact of firms' inflation perceptions on investment: Evidence from listed manufacturing enterprises in China
}

\author{
Chi Zhang ${ }^{1}$, Zhixin Liu ${ }^{1}$, and Lei Lv ${ }^{1, *}$ \\ ${ }^{1}$ School of Economics and Management, Beihang University, Beijing, China
}

\begin{abstract}
This article investigates the extent to which inflation perceptions affect firms' innovation input and investment expenditure. We adopt dummy variables data to quantify the firm inflation perceptions of China's listed manufacturing companies from corporate annual reports during the period from 2008-2018. Results reveal that inflation perceptions have a positive Tobin effect on investment spending decisions of the firms whose inflation perceive risen, vice versa. Besides, the investment expenditure of large manufacturing/ SOEs enterprises are more sensitive than small/non-SOEs firms when inflation perceptions have risen, and small/non-SOEs companies tend to reduce much more investment spending when inflation perceptions decline. Our results have significant implications for policymakers and firm managers.
\end{abstract}

\section{Introduction}

Since the rational expectations revolution in macroeconomics, inflation expectations play a central role in economists' analysis of inflation dynamics. Economic theory holds that inflation expectations affect a key determinant of people's economic decision-making and actual inflation. In addition, Georganas et al. (2014) suggest that perceptions of inflation also play a central role in macroeconomic analyses because they directly affect the decisions of individuals, organizations and states [1]. As some scholars argue that, it is just as important to investigate perceptions of inflation - what people think inflation has been in the past [2-3].

A strand of the literature in inflation perceptions is concerned with the perceptual formation and influencing factors. Ranyard et al. (2008) suggest that individual perception of inflation is influenced by both the individual's direct experience of price changes in the economy and by the media and the social amplification mechanism that is word of mouth [2]. Also, personal inflation perception is affected by personal income. Del et al. (2016) investigate two factors - product accessibility and attitudes towards inflation-that are expected to play a significant role in global judgments of perceived inflation [4]. Arioli et al. (2017) show that consumers hold different perceptions of inflation depending on their income, age, education and gender [5]. Hayo and Neumeier (2018) regard that individual's economic situation, information search and interest in inflation, economic knowledge, and attitudes and values are related to inflation perception [6]. Stanisławska (2019) shows that consumers' perception of inflation is affected by the inflationary environment [7]. Specifically, consumers' perception of inflation is more quickly to inflation increases than decreases. And the inflation perception is distorted during the deflationary period, leading to a smaller perception bias.

Setting aside the issue on inflation perceptual formation and influencing factors, the goal of this paper is to empirically evaluate whether and to what extent firms' inflation perceptions and investment are related. More specifically, we are interested in examining whether firms that percept higher past inflation are more or less willing to invest in the future. The literature regarding inflation perceptions on behavior is sparse. Much of this work has focused on individual or households, in part due to the greater availability of individual and households' surveys reporting inflation perceptions. For instance, Ranyard et al. (2008) argue that individual perceptions of inflation that affect an individual's economic behaviour (eg, consumption and savings decisions) [2]. Georganas et al. (2014) provide evidence that consumers' perceptions of aggregate inflation may affect consumers' consumption and investment decisions [1].

Yet, the literature regarding firms' inflation perceptions is even less due to the lack of available data. To this end, we take Chinese listed manufacturing companies as our research objects, according to the survey method of entrepreneurs' expectations for the future from the Chinese Business Operator Questionnaire Tracking Report (CBOQTR) firms' annual inflation perception dummy variables data from the price reports of listed companies in the annual

\footnotetext{
a The Chinese Business Operators Questionnaire Tracking Report (CBOQTR) is an annual survey of national entrepreneurs issued by the China Entrepreneur Survey System of the Development Research Center of the State Council. The report mainly tracks the business conditions of Chinese enterprises in terms of production, sales, inventory, profitability, and prosperity.
} 
reports published by the listed companies. To the best of our knowledge, obtain firms' annual inflation perception dummy variables data according to the survey method of entrepreneurs' expectations for the future from CBOQTR is the only way to obtain firms' inflation perception data. Thus, we can use the firm-level data to explore the impact of firms' inflation perceptions on investment behaviour and enrich the literature in this field.

The remainder of the paper is structured as follows: The research samples and data description are in Section 2. Section 3 is the empirical model and discussion of the results. Section 4 concludes.

\section{Research samples and data}

\subsection{Sample selection}

Before conducting the empirical analysis, we need to quantify the firms' perceptions. Refer to the concept of inflation perception index proposed by Brachinger (2008), which uses direct or indirect methods to obtain official data on price changes to measure firms' inflation perceptions [8]. The data of firms' inflation perceptions variables used in this paper are derived from the annual statements of Chinese listed manufacturing companies. A total of 457 companies were available for research by screening 877 sample companies. The specific screening process is described as follows:

As of June 2019, China's Shanghai and Shenzhen stock markets have a total of 3,624 A-share listed companies. The China Securities Regulatory Commission (CSRC) listed companies classified the listed companies into 19 categories, of which there are 2,334 under the category of manufacturing enterprises. The time interval for selecting sample data is 11 years from 2008 to 2018. To avoid the impact of short sample data on empirical research, companies that have been listed for less than 5 years are excluded from the search data and the final number of remaining companies is 877 .

The annual report of the sample company from 2008 to 2018 was obtained from the Wind Database. We require the firms' inflation perceptions data through manual screening. A statement similar to "the price of major products in this year has not changed much" indicates that the price of major products of the company has not changed during the year, and is represented by " 0 ". Similar to the "price increase of major products in this year", the statement "price increase of major products in this year" indicates that the price of major products of the enterprise has risen this year, which is represented by " 1 ". The statement of the opposite description indicates that the price of major products of the enterprise has decreased with "- 1 " to represent. Some statements like "The price of major products of the company has risen sharply this year", "the price of major products in this year has risen sharply" and "the price of products in this year has increased by $20 \%$ compared with the same period of last year" and other statements indicate that the price of major products of enterprises has risen sharply are represent by "2". The statement indicates that the price of the main products of the enterprise has dropped drastically and is represented by “-2".

Finally, the effective sample used in our study spans 11 years, from 2008 to 2018 (unbalanced panel). Given the availability of other financial variables, we got a total of 5026 observations.

\subsection{Variable description}

1. Dependent Variable: investment behavior

Referring to the method of Chen et al. (2011), we select the cash paid by companies for the purchase and construction of fixed assets and other long-term assets as the surrogate variable [9]. Using inv to indicate the ratio of cash paid for the purchase and construction of fixed assets to total assets then we have:

$$
\text { inv }=\frac{\text { Cash purchased from fixed assets }}{\text { Last period total assets }}
$$

2. Explanatory variables: firms' inflation perceptions

This paper examines the effect of firms' inflation perception on investment. The firms' inflation perception data used here is qualitative data and there are five different situations where multi-category dummy variables are used to represent firms' inflation perception data. The situation is that the price rises sharply, the price rises, the price remains the same, the price decreases, and the price drops sharply. According to the setting of multi-class dummy variables [10], we need to introduce four dummy variables to handle five inflation perception levels, and we used the 'stay about the same' group as the benchmark inflation perception level.

$$
\begin{array}{ll}
D_{1 i}=\left\{\begin{array}{cl}
\text { risen a lot } \\
\text { else }
\end{array}\right. & D_{2 i}=\left\{\begin{array}{c}
\text { risen mod erately } \\
\text { else }
\end{array}\right. \\
D_{3 i}=\left\{\begin{array}{c}
\text { fallen mod erately } \\
\text { else }
\end{array}\right. & D_{4 i}=\left\{\begin{array}{c}
\text { fallen a lot } \\
\text { else }
\end{array}\right.
\end{array}
$$

\section{Control variable}

Net cash flow from operating activities (cfo). Referring to Lang et al. (1996) and Richardson (2006) [11-12], we use the ratio of net cash flow from operating activities to total assets to reflect the company's cash flow capacity:

$C F O=\frac{\text { Net } \text { cash flow from operating activities }}{\text { Last period total assets }}$

Leverage (lev). Williamson (1987) believes that it is also a governance tool that has a restraining effect on the excessive investment behavior of enterprises [13]. In addition, the results of Suto's (2003) study show that debt levels and fixed asset growth are significantly positively correlated [14]. This paper uses the ending asset-liability ratio as an indicator variable:

$$
\text { Lev }=\frac{\text { Total liabilities }}{\text { Last period total assets }}
$$

Firms' size (size). The company's investment is closely related to the size of the firm, so we use the 
logarithm of the total assets of the previous period as one of the control variables of firm investment:

$$
\text { size }=\text { natural } \log \text { arithm of the total assets }
$$

Liquid assets(assets). Referring to Hoshi et al. (1992) [15], we use the ratio of liquid assets to total assets to reflect the company's liquidity:

$$
\text { assets }=\frac{\text { Liquid } \text { assets }}{\text { Last period } \text { total assets }}
$$

\subsection{Descriptive statistics}

Descriptive statistics on the relevant research variables of listed companies in the manufacturing industry can more intuitively observe the distribution characteristics of the observations of each variable, which will help us to carry out the next research. Descriptive statistics for all variables, as shown in Table 1:

Table 1. Descriptive Statistics of Variables

\begin{tabular}{cccccc}
\hline & Min & Max & Mean & Std. Dev. & Obs. \\
\hline inv & 0.041 & 0.545 & 0.056 & 0.054 & 5026 \\
IP & -2 & 2 & -0.273 & 1.149 & 3693 \\
cfo & -1.938 & 1.127 & 0.046 & 0.09 & 5026 \\
lev & 0.007 & 8.009 & 0.512 & 0.246 & 5026 \\
size & 17.388 & 26.582 & 22.196 & 1.305 & 5026 \\
assets & 0.042 & 1 & 0.505 & 0.179 & 5026 \\
\hline
\end{tabular}

From Table 1, we can see that the average investment expenditure is 0.056 , slightly higher than the minimum (0.041), but far below the maximum (0.545). The standard deviation indicates that the investment of listed manufacturing enterprises in China is relatively stable. The core explanatory variable inflation perceptions (IP) has a negative overall mean, indicating that firms' inflation perceptions are declining in the past few years.

\section{Empirical model and results}

\subsection{Empirical methodology}

To explore the impact of firms' inflation perception on business investment, we follow the majority of investment literature as shown in Model (2) (e.g., [9, 11, 16]):

$$
\operatorname{Inv}_{i, t}=\beta_{0}+\beta_{1} \operatorname{In} v_{i, t-1}+\sum_{k=1}^{4} \alpha_{k} D_{k, i, t-1}+\beta_{n} X_{n, i, t-1}+c_{i}+\mu_{i, t}
$$

Where $\operatorname{In} v_{i, t}$ denotes the new investment expenditure of firm $i$ at time $t$ and the lagged form of the investment variable is used to test the dynamic aspect of investment; $D_{k, i, t}$ indicates the $i$ firm's different inflation perception states at time $t-1, X_{n, i, t}$ includes the $i$ firm' finance variables at the end of year $t-1$, where $n=2,3,4,5 ; c_{i}$ is a time-invariance factor that indicates individual unobservable heterogeneity, and $\mu_{i, t}$ is an error assumed to be normally distributed (with mean zero and unitary variance).

Since there are lagging dependent variables, the dynamic panel data model (DPD) estimation will be adopted and estimated through the system GMM method.

\subsection{Empirical results and discussion}

Regression results of model (2) are summarized in Table 2.

\begin{tabular}{|c|c|c|c|c|}
\hline & \multicolumn{4}{|c|}{ Dependent Variable: Invt } \\
\hline & $\begin{array}{c}(1) \\
(\mathrm{OLS})\end{array}$ & $\begin{array}{c}(2) \\
(\mathrm{OLS})\end{array}$ & $\begin{array}{c}(3) \\
(\mathrm{GMM})\end{array}$ & $\begin{array}{c}\text { (4) } \\
(\mathrm{GMM})\end{array}$ \\
\hline$D_{1 i}$ & $\begin{array}{c}- \\
0.009 * * * \\
(0.005)\end{array}$ & & $\begin{array}{c}0.01 * * * \\
(0.003)\end{array}$ & \\
\hline$D_{2 i}$ & $\begin{array}{c}-0.003 \\
(0.002)\end{array}$ & & $\begin{array}{c}0.006^{* * *} \\
(0.002)\end{array}$ & \\
\hline$D_{3 i}$ & & $\begin{array}{c}0.002 \\
(0.002)\end{array}$ & & $\begin{array}{c}-0.006 * * * \\
(0.002)\end{array}$ \\
\hline$D_{4 i}$ & & $\begin{array}{c}0.012 * * * \\
(0.003)\end{array}$ & & $\begin{array}{c}-0.008 * * * \\
(0.003)\end{array}$ \\
\hline$I n v_{t-1}$ & & & $\begin{array}{c}0.591 * * * \\
(0.02)\end{array}$ & $\begin{array}{c}0.591 * * * \\
(0.021)\end{array}$ \\
\hline $\mathrm{CFO}_{t-1}$ & & & $\begin{array}{c}0.058 * * * \\
(0.014)\end{array}$ & $\begin{array}{c}0.058 * * \\
(0.014)\end{array}$ \\
\hline$L e v_{t-1}$ & & & $\begin{array}{c}-0.01 * * * \\
(0.003)\end{array}$ & $\begin{array}{c}-0.01 * * * \\
(0.003)\end{array}$ \\
\hline Size $_{t-1}$ & & & $\begin{array}{l}-0.0002 \\
(0.001)\end{array}$ & $\begin{array}{c}- \\
0.0001 * * * \\
(0.001)\end{array}$ \\
\hline Assets $_{t-1}$ & & & $\begin{array}{c}0.002 \\
(0.004)\end{array}$ & $\begin{array}{c}0.001 \\
(0.004)\end{array}$ \\
\hline _cons & $\begin{array}{c}0.06^{* * *} \\
(0.001)\end{array}$ & $\begin{array}{c}0.05 * * * \\
(0.001)\end{array}$ & $\begin{array}{c}0.021 \\
(0.015)\end{array}$ & $\begin{array}{l}0.027^{*} \\
(0.015)\end{array}$ \\
\hline $\mathrm{N}$ & 3419 & 3419 & 3151 & 3151 \\
\hline$R^{2}$ & 0.002 & 0.005 & 0.43 & 0.43 \\
\hline
\end{tabular}

Table 2. Investment and inflation perceptions: Results from multivariate tests

Note: Standard errors are noted in parentheses. ${ }^{* * *} \mathrm{p}<0.01,{ }^{* *}$ $\mathrm{p}<0.05, * \mathrm{p}<0.1$.

Model (2) investigates the effect of firms' inflation perceptions on firm-level investment. The rise in firms' inflation perceptions will reduce the growth of investment. The OLS estimate in Table 2 shows that firms with risen much inflation perceptions have a $0.9 \%$ lower investment expenditure than do firms whose inflation perceptions stay about the same. The negative relationship between firms' inflation perceptions and investment is change after adding the control variables term (cfo, lev, size, assets) by GMM regression, the coefficient of the inflation perceptions is positive, and it's still significant. It illustrates that manufacturing 
enterprises tend to increase the scale of investment rather than reduce when inflation perceptions increase. The result also verifies that there is a positive Tobin effect between inflation perceptions and firm investment. Firms with fallen inflation perceptions show a contrary conclusion to firms with risen inflation perceptions. In Table 2, the OLS estimate shows that firms with fallen a lot of inflation perceptions have a $1.2 \%$ higher investment expenditure than do firms whose inflation perceptions stay about the same. The GMM estimate shows firm investment spending is reduced by about 0.60.8 percentage points compared to normal conditions when firms' inflation perceptions as decline.

The coefficients of the lagged investment are all significantly positive. In regression (3) and (4), the coefficient and significance of control variables term (cfo, lev, size, assets) are basically the same.

\subsection{The effect in different sub-samples}

To explore whether a company's characteristic variables play a role in the relationship between inflation perceptions and investment, we separate the total sample into several sub-samples in this section.

\subsubsection{Impact of inflation perceptions on large and small firms}

We first use firm size as a proxy for capital market access and examine whether the impact of inflation perceptions on investment varies by firm size. The results are reported in Table 3.

Table 3. Impact of inflation perceptions on large and small firms
We find that the effect of inflation perceptions on corporate investment has significant differences among enterprises of different sizes. Compared with the full sample results in Table 2, large enterprises have increased much more investment expenditure when inflation perceptions have risen, and investment spending is decreasing less when inflation perceptions decline. The sample of small enterprises has the opposite conclusion. These results are consistent with the positive Tobin effect theory. At the same time, compared with small companies, large companies have more investment spending when inflation perceptions have risen, and less investment expenditure when inflation perceptions decline. Significantly different from the full sample regression in Table 2, the leverage ratio of large companies is significantly negative, while the small enterprises are not significant, but the size of small enterprises is significantly negative.

The comparison results show that the corporate investment expenditure of large manufacturing enterprises in China are more sensitive than small firms when inflation perceptions have risen, and small companies tend to reduce much more investment spending when inflation perceptions decline. As Grasso and Ropele (2016) research shows, the credit markets' access conditions and the expected liquidity position of firms are determinants of investment expectations [17]. This conclusion may be due to the fact that in China, large companies are generally more likely to enter the credit market and have better liquidity conditions, so their positive Tobin effect is more significant than that of small companies.

\begin{tabular}{|c|c|c|c|c|c|c|c|c|}
\hline & \multicolumn{8}{|l|}{ Firms' Size } \\
\hline & \multicolumn{4}{|l|}{ Large } & \multicolumn{4}{|l|}{ Small } \\
\hline & (1) & (2) & (3) & (4) & (5) & (6) & (7) & (8) \\
\hline & (OLS) & (OLS) & (GMM) & (GMM) & (OLS) & (OLS) & (GMM) & (GMM) \\
\hline$D_{1 i}$ & $\begin{array}{c}-0.011 * * * \\
(0.006)\end{array}$ & & $\begin{array}{l}0.012 * * \\
(0.005)\end{array}$ & & $\begin{array}{l}-0.011 \\
(0.007)\end{array}$ & & $\begin{array}{l}0.006^{*} \\
(0.003)\end{array}$ & \\
\hline$D_{2 i}$ & $\begin{array}{l}-0.004 \\
(0.003)\end{array}$ & & $\begin{array}{l}0.004 * \\
(0.002)\end{array}$ & & $\begin{array}{c}-0.003 \\
(0.003)\end{array}$ & & $\begin{array}{c}0.008 * * * \\
(0.002)\end{array}$ & \\
\hline$D_{3 i}$ & & $\begin{array}{c}0.003 \\
(0.003)\end{array}$ & & $\begin{array}{c}-0.005 * * \\
(0.002)\end{array}$ & & $\begin{array}{c}0.002 \\
(0.003)\end{array}$ & & $\begin{array}{c}-0.007 * * * \\
(0.002)\end{array}$ \\
\hline$D_{4 i}$ & & $0.014 * * *(0.004)$ & & $\begin{array}{l}-0.006^{*} \\
(0.003)\end{array}$ & & $\begin{array}{l}0.01 * * \\
(0.004)\end{array}$ & & $\begin{array}{c}-0.009 * * \\
(0.004)\end{array}$ \\
\hline $\operatorname{In} v_{t-1}$ & & & $\begin{array}{c}0.627 * * * \\
(0.03)\end{array}$ & $\begin{array}{c}0.626^{* * *} \\
(0.03)\end{array}$ & & & $\begin{array}{c}0.524 * * * \\
(0.03)\end{array}$ & $\begin{array}{c}0.525^{* * *} \\
(0.03)\end{array}$ \\
\hline$C F O_{t-1}$ & & & $\begin{array}{c}0.082 * * * \\
(0.021)\end{array}$ & $\begin{array}{c}0.081 * * * \\
(0.021)\end{array}$ & & & $\begin{array}{c}0.033 * * * \\
(0.01)\end{array}$ & $\begin{array}{c}0.033^{* * *} * \\
(0.01)\end{array}$ \\
\hline$L e v_{t-1}$ & & & $\begin{array}{c}-0.02 * * * \\
(0.006)\end{array}$ & $\begin{array}{c}-0.02 * * * \\
(0.006)\end{array}$ & & & $\begin{array}{l}-0.005 \\
(0.004)\end{array}$ & $\begin{array}{l}-0.005 \\
(0.004)\end{array}$ \\
\hline Size $_{t-1}$ & & & $\begin{array}{l}-0.001 \\
(0.001)\end{array}$ & $\begin{array}{c}-0.001 \\
(0.001)\end{array}$ & & & $\begin{array}{c}-0.004 * * * \\
(0.002)\end{array}$ & $\begin{array}{c}-0.004 * * \\
(0.002)\end{array}$ \\
\hline Assets $_{t-1}$ & & & $\begin{array}{l}-0.003 \\
(0.005)\end{array}$ & $\begin{array}{l}-0.004 \\
(0.005)\end{array}$ & & & $\begin{array}{c}0.003 \\
(0.007)\end{array}$ & $\begin{array}{c}0.003 \\
(0.007)\end{array}$ \\
\hline _cons & $\begin{array}{l}0.07 * * * \\
(0.002)\end{array}$ & $\begin{array}{l}0.06^{* * * *} \\
(0.002)\end{array}$ & $\begin{array}{c}0.046^{* *} \\
(0.02)\end{array}$ & $\begin{array}{c}0.05^{* *} \\
(0.02)\end{array}$ & $\begin{array}{c}0.05 * * * \\
(0.002)\end{array}$ & $\begin{array}{c}0.05^{* * *} \\
(0.002)\end{array}$ & $\begin{array}{c}0.1 * * * \\
(0.03)\end{array}$ & $\begin{array}{l}0.11 * * \\
(0.03)\end{array}$ \\
\hline
\end{tabular}




$\begin{array}{lcccccccc}\mathrm{N} & 1733 & 1733 & 1586 & 1586 & 1686 & 1686 & 1565 & 1565 \\ R^{2} & 0.003 & 0.006 & 0.5 & 0.5 & 0.002 & 0.002 & 0.35 & 0.35\end{array}$

Note: Standard errors in parentheses, ${ }^{* * *} \mathrm{p}<0.01,{ }^{* *} \mathrm{p}<0.05,{ }^{*} \mathrm{p}<0.1$; Average size of each enterprise in all years is used to separate firms into large size and small size. The number of large companies is 228, and the sample of small companies is 229.

\subsubsection{Impact of inflation perceptions on SOEs and non-SOEs}

According to the attributes of the major shareholder/actual controller of the company, we divide the ownership type of the enterprise into state-owned enterprises and non-state-owned enterprises (SOEs and non-SOEs). We further divide the overall sample into SOEs and non-SOEs and the results are given in Table 4.

We find that the effect of inflation perceptions on corporate investment has significant differences among enterprises of different company attribute. Compared with the full sample results in Table 2, SOEs enterprises have increased much more investment expenditure when inflation perceptions have risen, and investment spending is decreasing less when inflation perceptions decline. The sample of non-SOEs enterprises has the opposite conclusion. These results are consistent with the positive Tobin effect theory. At the same time, compared with non-SOEs companies, large SOEs have more investment spending when inflation perceptions have risen, and less investment expenditure when inflation perceptions decline. Significantly different from the full sample regression in Table 2, for state-owned enterprises, liquid assets have a significant negative impact on corporate investment, while for non-state-owned enterprises, the coefficient of current assets is significantly positive.

Table 4. Impact of inflation perceptions on SOEs and non-SOEs

\begin{tabular}{|c|c|c|c|c|c|c|c|c|}
\hline & \multicolumn{8}{|c|}{ Ownership Type } \\
\hline & SOEs & & & & non-SOEs & & & \\
\hline & (1) & (2) & (3) & (4) & (5) & (6) & (7) & (8) \\
\hline & (OLS) & (OLS) & (GMM) & (GMM) & (OLS) & (OLS) & (GMM) & (GMM) \\
\hline$D_{1 i}$ & $\begin{array}{c}-0.004 \\
(0.006)\end{array}$ & & $\begin{array}{c}0.015 * * * \\
(0.005)\end{array}$ & & $\begin{array}{c}-0.014 * * \\
(0.007)\end{array}$ & & $\begin{array}{c}0.005 \\
(0.004)\end{array}$ & \\
\hline$D_{2 i}$ & $\begin{array}{c}0.002 \\
(0.003)\end{array}$ & & $\begin{array}{c}0.006 * * * \\
(0.002)\end{array}$ & & $\begin{array}{c}-0.008 * * * \\
(0.003)\end{array}$ & & $\begin{array}{l}0.005^{* *} \\
(0.002)\end{array}$ & \\
\hline$D_{3 i}$ & & $\begin{array}{l}-0.004 \\
(0.003)\end{array}$ & & $\begin{array}{c}-0.008 * * * \\
(0.002)\end{array}$ & & $\begin{array}{c}0.008 * * * \\
(0.003)\end{array}$ & & $\begin{array}{l}-0.004^{*} \\
(0.002)\end{array}$ \\
\hline$D_{4 i}$ & & $0.009 * *(0.004)$ & & $\begin{array}{l}-0.006 \\
(0.004)\end{array}$ & & $\begin{array}{c}0.015^{* * *} \\
(0.005)\end{array}$ & & $\begin{array}{c}-0.011 * * * \\
(0.004)\end{array}$ \\
\hline $\operatorname{In} v_{t-1}$ & & & $\begin{array}{c}0.59 * * * \\
(0.03)\end{array}$ & $\begin{array}{c}0.59 * * * \\
(0.03)\end{array}$ & & & $\begin{array}{c}0.59 * * * \\
(0.03)\end{array}$ & $\begin{array}{c}0.59 * * * \\
(0.03)\end{array}$ \\
\hline$C F O_{t-1}$ & & & $\begin{array}{c}0.064 * * * \\
(0.021)\end{array}$ & $\begin{array}{c}0.063 * * * \\
(0.021)\end{array}$ & & & $\begin{array}{c}0.047 * * * \\
(0.013)\end{array}$ & $\begin{array}{c}0.047 * * * \\
(0.013)\end{array}$ \\
\hline$L e v_{t-1}$ & & & $\begin{array}{c}-0.012 * * * \\
(0.004)\end{array}$ & $\begin{array}{c}-0.012 * * * \\
(0.004)\end{array}$ & & & $\begin{array}{l}-0.009 * \\
(0.005)\end{array}$ & $\begin{array}{l}-0.008 \\
(0.005)\end{array}$ \\
\hline Size $_{t-1}$ & & & $\begin{array}{c}-0.001 \\
(0.001)\end{array}$ & $\begin{array}{c}-0.001 \\
(0.001)\end{array}$ & & & $\begin{array}{c}0.001 \\
(0.001)\end{array}$ & $\begin{array}{c}0.001 \\
(0.001)\end{array}$ \\
\hline Assets $_{t-1}$ & & & $\begin{array}{l}-0.011^{*} \\
(0.006)\end{array}$ & $\begin{array}{l}-0.011^{*} \\
(0.006)\end{array}$ & & & $\begin{array}{c}0.017 * * * \\
(0.006)\end{array}$ & $\begin{array}{c}0.016 * * * \\
(0.006)\end{array}$ \\
\hline _cons & $\begin{array}{l}0.05^{* * *} \\
(0.002)\end{array}$ & $\begin{array}{c}0.06^{* * *} \\
(0.002)\end{array}$ & $\begin{array}{l}0.04 * * \\
(0.02)\end{array}$ & $\begin{array}{l}0.05^{* *} \\
(0.02)\end{array}$ & $\begin{array}{c}0.06^{* * * *} \\
(0.002)\end{array}$ & $\begin{array}{c}0.05^{* * *} \\
(0.002)\end{array}$ & $\begin{array}{l}-0.016 \\
(0.03)\end{array}$ & $\begin{array}{l}-0.009 \\
(0.03)\end{array}$ \\
\hline $\mathrm{N}$ & 1801 & 1801 & 1653 & 1653 & 1618 & 1618 & 1498 & 1498 \\
\hline$R^{2}$ & 0.001 & 0.007 & 0.45 & 0.45 & 0.007 & 0.008 & 0.41 & 0.41 \\
\hline
\end{tabular}

Note: Standard errors in parentheses, $* * * \mathrm{p}<0.01, * * \mathrm{p}<0.05, * \mathrm{p}<0.1$; State-owned enterprises include central state-owned enterprises (large shareholders/actual controllers belong to the State-owned Assets Supervision and Administration Commission(SASAC), central state organs or central state-owned enterprises or institutions) and local state-owned enterprises (large shareholders/actual controllers belong to local SASAC, local levels government/department or local state-owned enterprise/institution). The enterprises that are not part of the state-owned enterprise ownership system are all classified as non-stateowned enterprises. The number of SOEs companies is 230, and the sample of non-SOEs is 227. 
The comparison results show that the corporate investment expenditure of SOEs manufacturing enterprises in China are more sensitive than non-SOEs firms when inflation perceptions have risen, and nonSOEs companies tend to reduce much more investment spending when inflation perceptions decline. As the same of [17], this conclusion may be due to the fact that in China, SOEs companies are generally more likely to enter the credit market and have better liquidity conditions, so their positive Tobin effect is more significant than that of non-SOEs companies.

\section{Conclusion}

In this article, we analyse the effect of firms' inflation perceptions on investment decision, using panel data of listed manufacturing companies in China from 2008 to 2018.

The research results indicate that inflation perceptions have a positive Tobin effect on investment decision behaviours. It illustrates that manufacturing enterprises tend to increase the scale of investment rather than reduce when inflation perceptions increase. Our baseline results by GMM method show that firms with risen inflation perceptions have an approximately $0.6 \% \sim 1 \%$ higher investment expenditure than do firms with inflation perceptions that remain about the same. When firms' inflation perception is in a contraction phase, corporate investment spending will decrease by about 0.6-0.8 percentage points compared to the benchmark group. Furthermore, the corporate investment expenditure of large manufacturing enterprises in China are more sensitive than small firms when inflation perceptions have risen, and small companies tend to reduce much more investment spending when inflation perceptions decline. For SOEs and non-SOEs enterprises, the comparison results show that the corporate investment expenditure of SOEs manufacturing enterprises in China are more sensitive than non-SOEs firms when inflation perceptions have risen, and nonSOEs companies tend to reduce much more investment spending when inflation perceptions decline.

This paper contributes to the literature on firms' investment expenditure in two main respects: (1) we focus specifically on the role of inflation perceptions, a variable typically ignored by most firms' investment spending determination studies due to lack of data availability; (2) we find that China's listed manufacturing companies have a positive Tobin effect. This has implications for studying the ongoing debate of long-run relationship between inflation and investment.

\section{Acknowledgments}

The research was supported by the National Natural Science Foundation of China (No.71873014).

\section{References}

1. Georganas S, Healy P J, Li N. (2014) Frequency bias in consumers? perceptions of inflation: An experimental study. J. European Economic Review., 67: 144-158.

2. Ranyard, R., Missier, F. D., Bonini, N., Duxbury, D., and Summers, B. (2008). Perceptions and expectations of price changes and inflation: a review and conceptual framework. Journal of Economic Psychology, 29(4): 378-400.

3. Axelrod, S., Lebow, D. E., and Peneva, E. (2018). Perceptions and Expectations of Inflation by US Households.

4. Del M. F., Ranyard, R., and Bonini, N. (2016). Perceived inflation: The role of product accessibility and attitudes towards inflation. Journal of Economic Psychology, 56: 97-106.

5. Arioli, R., Bates, C., Dieden, H., Duca, I., Friz, R., Gayer, C., and Pavlova, I. (2017). EU consumers' quantitative inflation perceptions and expectations: An evaluation (No. 186). ECB Occasional Paper.

6. Hayo, B., and Neumeier, F. (2018). Households' Inflation Perceptions and Expectations: Survey Evidence from New Zealand.

7. Stanisławska, E. (2019). Consumers' perception of inflation in inflationary and deflationary environment. Journal of Business Cycle Research, 15(1): 41-71.

8. Brachinger, H. W. (2008). A new index of perceived inflation: Assumptions, method, and application to Germany." Journal of Economic psychology.29(4): 433-457.

9. Chen S, Sun Z, Tang S, et al. (2011). Government intervention and investment efficiency: Evidence from China. Journal of Corporate Finance, 17(2): 259-271.

10. Wooldridge, Jeffrey M. (2013). Introductory Econometrics: A Modern Approach. 5th ed. Mason, $\mathrm{OH}$ : South-Western.

11. Lang, L., Ofek, E., and Stulz, R. (1996). Leverage, investment, and firm growth. Journal of Financial Economics,40(1): 3-29.

12. Richardson S. (2006). Over-investment of free cash flow. Review of Accounting Studies, 11(2-3): 159189.

13. Williamson S.D. (1987). Costly Monitoring, Loan Contracts and Equilibrium Credit Rationing. Quarterly Journal of Economics, 102: 135-146.

14. Suto, M. (2003). Capital structure and investment behaviour of Malaysian firms in the 1990s: a study of corporate governance before the crisis. Corporate Governance: An International Review,11(1): 25-39.

15. Hoshi T, Anil K, and David S. (1991). Corporate structure, liquidity and investment: Evidence from Japanese industrial groups. Quarterly Journal of Economics, 106: 33-60. 
16. Cao, H., Guo, L., and Zhang, L. (2019). Does oil price uncertainty affect renewable energy firms' investment? Evidence from listed firms in China. Finance Research Letters.

17. Grasso, A., and Ropele, T. (2016). Business investment plans and inflation expectations. In CESifo Conference on Macroeconomics Survey Data, 2-3 December. 